\title{
$\longrightarrow$ \\ Affective Futures and Relative Eschatology in American Tibetan Buddhism
}

\author{
Amy Binning
}

ABSTRACT: Tibetan Buddhist prophecies of decline are largely unattended when it comes to practitioners' lived experiences. This article considers such narratives through a focus on a community of American Buddhists in California. The relationship between Buddhist narratives of degenerating future and the American landscape is played out through the creation and distribution of sacred objects, which are potent containers for-and portents of-prophetic futures. Ruptures in time and landscape become, through the frame of prophecy, imaginative spaces where the American topography is drawn into Tibetan history and prophetic future. Narratives of decline, this article argues, also find common ground with salient American rhetoric of preparedness and are therefore far from fringe beliefs, but a more widely available way of thinking through quotidian life.

KEYWORDS: affective temporality, decline, future, Kaliyuga, landscape, preparedness, prophecy, sacred materials

Along threatening fault lines in California's landscape there are thousands of small votives called tsha-tshas buried in the earth. Thousands more of their twins have been submerged in the ocean off California and Japan's coasts following tsunamis or storms. Still more are interred at Auschwitz-Birkenau in a project titled "Planting Seeds of Healing." These tsha-tshas have all been shaped and distributed by one community of Nyingma Tibetan Buddhists based in Berkeley, California. They have done so under the direction of their founding lama, Tarthang Tulku, who fled Tibet for California, via India, in the 1960s. One of Tarthang Tulku's students described tshatshas to me as the topical healers of the Tibetan Buddhist sacred art world: applied like a bandage to the fissures and blemishes of the landscape, they soothe, placate, and hold together tempestuous terrain. This is a somewhat historically unique understanding of the tsha-tsha, which nevertheless draws on their established role as purifiers of negative karma. These little votives, though, are only the foot soldiers in a larger campaign that seeks to hold together the very ground under our feet in the face of a precipitous decline prophesied in Buddhist scripture-a moral, spiritual, and environmental decline so complete that natural disasters are only its warning shots.

Many have rightly pointed out Tibetan Buddhism's (often strategic) affiliation with the nebulous idea of the 'traditional' in the West. Appeals to Tibet's precarious and valuable tradition, antiquity, and spiritual depth threatened by the encroachment of a relentless modernity play 
remarkably well with American and international audiences (Anand 2007; Barnett 2001; Hess 2006; Lopez 1998). Still others have commented on the ability of the advocates of Tibetan Buddhism in America to trade in the ideological currencies beloved of modernity, projecting an image of Buddhism that is compatible with science, contemporary values, and even secularism(s) (McMahan 2008, 2017). Tibetan Buddhism's affiliation with the past and present in America, then, are well accounted for. But what of its relationship to the future?

In this piece I will explore another point of engagement between Tibetan Buddhism, its practitioners, and the American religious and temporal landscape, that is, through the affective experience of narratives of preparedness, disaster, and decline. Buddhism's prophecies of decline-common across nearly all schools-place our current moment on a downward fall that stretches millennia into the future, to a final depth when Buddhism itself is forgotten. Only after these trials have been weathered is there hope for a very distant peak when the future Buddha, Maitreya (Tib. byams pa), will appear. Extant studies of this prophetic decline are largely scriptural in nature. These sources are undoubtedly rich, but what I intend to offer here is an ethnographically embedded investigation of what it is to live these temporalities.

I aim to shed light on Tibetan Buddhism's relationship to the future in America by way of the small group of Nyingma Buddhist practitioners in Berkeley, called the Tibetan Nyingma Meditation Center (TNMC), who are responsible for those many thousands of tsha-tshas interred in California and abroad. The little tsha-tshas that pepper the American landscape, together with their makers, offer a narrative that may diversify our understanding of the affective temporality of American Buddhism. While this group may be unique, examining its work opens the door to a future-oriented American Buddhist practice that can be categorized as a 'relative eschatology'. In the first section I will outline the narratives of decline that suffuse TNMC's practices, the prophecies they refer to, and how they become hitched to quotidian life at the center in a manner that might be described as a kind of 'everyday millenarianism' (Robbins 2001).

Next, I will show how this prophesied downward slide precipitates a period of intense activity, one filled with practices of proliferating, caching, and distributing sacred materials as the 'critical infrastructure' of the Tibetan Buddhist tradition in a way that connects to Nyingma Buddhist history, but also finds commonality with American narratives of 'preparedness' (Lakoff 2007). Not only does this relative eschatology become 'everyday' to practitioners in this community, then, but I suggest that the sense of living alongside impending cataclysm is a more widely identifiable affective theme in the American temporal landscape. Finally, I will show how sacred art and text act as particularly effective temporal containers for this community. As objects that are both portents of and salves to the coming decline, sacred materials fix Buddhist prophetic narratives to the bodies of their makers as well as the surrounding landscape. TNMC's engagement with the sacred objects they create-in particular sacred text and art, such as tshatshas, stupas, banners, and flags-is not solely a bid to proliferate 'traditional' forms, but rather represents a critical site of coming to know the future and rendering it actionable. The temporal and topographical ruptures that TNMC's sacred objects address create spaces where the fertile, imaginative dimensions of prophecy come to fruition, revealing entanglements between Tibet's history and landscape and this distant Californian outpost, drawn together in a prophetic future and an anticipatory present.

\section{Ruptures: Relative Eschatology and Everyday Decline}

The threat of earthquakes is a recurring theme in daily life at the Tibetan Nyingma Meditation Center. Many of the sacred objects its members labor to create, like the tsha-tshas, are specifically 
designed to placate or subdue impending quakes. Given the increasing public discussion of a catastrophic earthquake due to hit the Northwest coastal region of the US, ${ }^{1}$ it is perhaps not unusual that earthquakes emerge as a highly salient threat incorporated into narratives of decline as they are elaborated at TNMC. The relatively frequent occurrence of earthquakes and wildfires across California create ruptures in the temporal and spatial surroundings. Those ruptures produce a rough surface where TNMC hitches imagined future (and ever worsening) catastrophes. It is this future-looking sense of threat undergirded by very real past occurrences that allows California's natural disasters to be recast as part of a wider narrative of decline, for such disasters are also a common recurrence in Tibetan accounts of our present degenerate age. The landscape's blemishes and ruptures can also be productive, as the cracks they open provide fertile room for imaginative labor that links American topography to Tibet's Buddhist history and its prophetic future. The precarity of California's landscape coupled with Tarthang Tulku's acute experiences of the recent threats to Buddhism in Tibet come together here to draw out a prophetic and apocalyptic manifestation of Tibetan Buddhist temporal reckoning. Through sacred objects such as Tibetan flags and tsha-tshas, Tarthang Tulku's teaching recasts California's familiar threats as part of a broader decline tied to the endangerment of Tibetan Buddhism.

In the temperamental Berkeley spring, about six months into my fieldwork with the TNMC, I joined the group's annual sacred flag-printing project. ${ }^{2}$ A small group of us worked in an empty parking space behind one of the community buildings, using large custom-made screens to print hundreds of brightly colored flags with Tibetan text. Clara, a bespectacled senior member of the community with flyaway blonde hair, had been in charge of the annual flag-printing run for years. When I asked what text we were working with, though, she told me that she did not know its name, but did know that it was chosen for its stabilizing qualities, here intended to prevent earthquakes. That Clara did not know the text's name is not unusual. Tibetan language is studied by only a very few of Tarthang Tulku's particularly enthusiastic students, and the matter of how to use which texts and when is left primarily to him. Clara did know, however, that these particular flags were too potent to be flown in Berkeley's crowded urban landscape and to attempt it would be "like driving a freight train through downtown Berkeley." They would instead be sent to Odiyan, the palatial Sonoma property where Tarthang Tulku resides with a small cohort of followers. In spite of their Tibetan illiteracy, TNMC's volunteers have an intimate and bodily understanding of the power of Tibetan script born of experience working with rather than studying Tibetan text. This is reflected not only in Clara's acute sense that these particular flags had all the power of a freight train, but also in the reverence and gravity with which she and the other volunteers approached working with them.

In fact, it was not until well after the project had begun that I learned what text it was that we labored over. To do so, I had to speak to Ray, another long-time student of Tarthang Tulku, who teaches the annual (thinly attended) Tibetan language class. ${ }^{3}$ The earthquake-soothing text we worked with, Ray told me, is called the Earth Heart Ten Wheel Sutra (Tib. sa'i snying po 'khor lo bcu pa), and it invokes the Bodhisattva Ksitigarbha whose name translates to something like 'Earth Treasury'. The passages and their association with Ksitigarbha and the earth are here intended to have a placating effect on California's landscape. Like Clara, Ray impressed upon me the flags' intimate entanglement with the topography. To illustrate the kind of effect they might have, he told me a story of visiting Odiyan and recognizing immediately that the land simply "looked good" in a way that was obvious but difficult to define, "like after a good rain." When an Odiyan resident explained to Ray that Tarthang Tulku had performed a ceremony earlier that day to placate the surrounding landscape and its inhabitants, Ray knew immediately that this explained what he saw and felt. These potent flags, he explained, would have a similar tangible and instant effect. 
The flags, however, also look beyond the kind of immediate effect Ray described. One day, while working through Berkeley's alternating fog and heat, I pointed to a Tibetan line in a tiny font at the very bottom of a flag, joking that perhaps the typesetters had had a difficult time squeezing this passage onto their template. Clara, though, pointed out two similar small lines at the bottom of every screen. They repeated the same phrase in English and in Tibetan: "Dedicated to the longevity of Tarthang Tulku Rinpoche." Each and every flag TNMC produces has such a translated line appended to the main body of text. The idea, she explained, is that if all other traces of the Tibetan language (the key to its rich textual tradition) were to disappear, it could be reconstructed using these two lines as a kind of legend. Each of the hundreds of flags we created in those several days manifests a Rosetta Stone-like potential to resurrect Tibetan Buddhist wisdom in a distant future when it has been forgotten. Each flag, then, contains multiple layered bids at preservation: to shore up the longevity of the teacher, to placate the tempestuous earth upon which it is planted, and to safeguard the very language of Tibetan Buddhism that holds the key to its wisdom.

The broader decline that these colorful flags reference is one embedded in Buddhism's understanding of our current era. Buddhism's dominant approach to temporality is an understanding of impermanence so complete that its philosophers acknowledge that even the religion itself is doomed to disappear (Nattier 2008). ${ }^{4}$ Under the auspices of this ultimate impermanence, though, the Buddhist reckoning of our world's progression describes a cyclic regeneration that oscillates between phases of peak moral and spiritual manifestation and the depths of degeneracy wherein the Buddha's teachings are forgotten. The see-sawing of the world's manifestation is specifically elaborated in the Abhidharmakośa (Tib. chos mngon pa'i mdzod). ${ }^{5}$ This sutra describes an immense temporal frame as divided into four nearly immeasurably long ages, or kalpas: an age of progressive destruction when the world slides into disrepair; an age of the duration of destruction when the universe is 'non-manifest'; an age of renovation when the world reappears and is repopulated; and an age of the duration of renovation during which the universe remains manifest and filled with life (Nattier 1991: 15-16). We currently occupy a point somewhere in the kalpa of progressive destruction (although where exactly we are within its subdivided ages is not agreed upon), and the appearance of the future Buddha Maitreya's appearance in roughly 5.6 billion years (give or take 500 million to account for disagreements between sources) will mark the apex of the coming era of renovation.

Sakyamuni Buddha predicted the disappearance of his own teachings, as recounted in the Candragarbha sutra (Tib. Byang chub sems dpa' zla ba'i snying pos zhus pa las lung bsta pa) in which the Buddha describes to his followers the gradual decline and eventual disappearance of the dharma in the centuries following his death. During the final reaches of this downfall, Buddhism's protective deities abandon this world, leaving its inhabitants to "an onslaught of illness, famine, and warfare" (Nattier 1991: 176). The human life span will decline to a paltry 10 years, and our short lives will be plagued by disasters and floods. As humanity's moral fiber disintegrates, we will live increasingly as though "under a knife" (Borjigin 2006: 32).

Buddhists and Hindus broadly share the above described vision of the universe as oscillating through four ages. In the Hindu renderings, the period of decline is further divided into four phases or yugas. The lowest and most degenerate of these, called the 'Kaliyuga', is the phase many believe we are in or approaching. ${ }^{6}$ The Kaliyuga, then, while a Hindu term, is embedded in a temporal understanding it shares with Buddhism, and thus appears to be one of the many Sanskrit terms that has occasionally slipped across the shared boundary between the two traditions. Some Buddhists, Tarthang Tulku and his students among them, have taken up the term 'Kaliyuga' - in reference to the desolate kalpas that both traditions share-to describe the present era.

Buddhism's approach to the future has been depicted as a 'relative eschatology' (Apple 2010, referencing Zwi Werblowsky). It is relative in the sense that, insofar as eschatology refers to the 
end and final judgment of humankind, Buddhism's cyclic regenerative understanding of temporality means that its endings are not an absolute end to the world but rather an end to the world as we know it. In Tarthang Tulku's community, the general understanding that Buddhist practice-and the world more generally - is in the throes of a decline takes on distinctly cataclysmic framings. The sutras described above, which explicitly mention threats to the Buddhist sangha (community), natural disasters, and mounting warfare, among other misfortunes, undoubtedly allow for events like California's earthquakes to be read as signposts of our age of decline. The specific context of China's Cultural Revolution (1966-1976) and the threat its aftermath continues to pose to Tibetan Buddhism accounts for part of the urgency that pervades this particular manifestation of prophetic decline. Tarthang Tulku fled Tibet amid the ravages of the Cultural Revolution, which directed specific ire at Tibetan Buddhist practitioners, art, textual material, and monasteries as manifestations of the 'Four Olds' of pre-Communist China that it sought to destroy (Diemberger 2012). His efforts since the 1960s have been primarily in service of shoring up these cultural stores through the urgent, widespread proliferation of Tibetan writing and art. His community has been populated by individuals steeped in the American awareness of Tibet's plight that caught fire in the 1960s-1970s and has remained at a slow burn ever since. Indeed, many of his students recount that it was this awareness, coupled with a measure of spiritual seeking, that drove them to join TNMC.

The ubiquity of cataclysm-inspired projects like the prayer flags perpetuates a sense that the volunteers at the Tibetan Nyingma Meditation Center are living with, alongside, and in anticipation of destructive events in a kind of relative eschatology that resembles Robbins's (2001) description of 'everyday millenarianism'. We often expect that millenarianism is by its very nature 'not normal', and that its certainty about impending end times must naturally lead to the kind of withdrawal from the world that is the province of short-lived movements and cults. ${ }^{7}$ However, Robbins points out that millenarianism can, and often does, provide a quotidian framework that is meaningful to social life and crucial to the way in which people "think through stretches of time" (ibid.: 528).

The kind of relative millennialism that characterizes Tarthang Tulku's Berkeley community, then, is more akin to this everyday cohabitation with the specter of decline. Although there is no halting the degeneration, there is a horizon beyond it where one can hope to attain a rebirth that will allow an encounter with Maitreya and the favorable practice conditions that this Buddha brings. There is still, however, a distinct sense of living on a slope that threatens to cascade out from under us. Although the depths of this era of decline may be millennia away, the cataclysms that are its calling card could strike at any moment. Thus, there remains an element of temporal balancing - a reckoning of imminent and far distant futures in this temporal landscape in which the far distant future is repeatedly folded into the present, heaving up in daily life in ways that must be managed. If we allow this sort of imminence, which is critically entangled with topography, to come to the fore, narratives of the coming decline and the salvific appearance of Maitreya readily take on millennial characteristics (Collins 1998).

For Tarthang Tulku, narratives of the Kaliyuga allow a framing that ties the topographical threats that his followers are intimately familiar with to the threat facing Tibet's textual lineage and practice, which has drawn followers to his projects. The earth's ruptures, then, are productive in terms of how TNMC locates itself in the temporal and topographical landscape of Tibetan Buddhism. It is difficult to overstate the cultural salience of landscape in Tibet. Through a Buddhist lens, Tibet's many peaks, valleys, and lakes are pregnant with an array of spiritual or demonic presences (Huber 1999), and the ability to marshal such presences to Buddhist cosmologies has been a central element of its spread throughout Tibet and the surrounding areas (ibid.; see also Smyer Yü 2012). In particular, specific sites and objects in Tibet's topography are 
sometimes said to offer a direct connection or relationship to India, whose invocation as the much-revered origin of Sakyamuni Buddha and the source of his teachings lends a great deal of spiritual puissance and legitimacy (Huber 2008).

Odiyan - the destination of the sacred flags I helped to labor over-and the many sacred objects that populate it perform a similar function. Through narrative and landscape, Odiyan creates bridges that siphon the spiritual gravity and history of Tibet's powerful landscape to enliven the Californian topography. Odiyan's design is laid out on the California terrain in the shape of a mandala, a powerful device with a notable history in placating and subduing landscape (Huber 1999; Macdonald 1996). Its name is drawn from Uddiyanna, supposedly the residence of Padmasambhava (located west of Tibet) (Bogin 2014), the deeply treasured figure who is credited with bringing Buddhism to Tibet and, in the process, soothing and subduing Tibet's previously threatening landscape (Dalton 2011). Through its capacity to quell this new landscape, Odiyan casts Tarthang Tulku as California's Padmasambhava, bringing Buddhism to bear on its terrain. The earthquakes referenced by the flags and tsha-tshas produced by this community are an example of the way familiar features in California's landscape become places to fix a broader Buddhist narrative of deterioration that can be addressed through shoring up Tibetan Buddhism. Thus, the ruptures introduced by disasters allow space in which the fertile dimensions of the Kaliyuga and its temporality come to fruition. Investing these spaces with prophetic imaginings of the future reveals connections between the American landscape and the Tibetan landscape, between American time and Tibetan Buddhist prophetic time.

\section{Guidestones: Critical Infrastructure and American Preparedness}

In June 1979, against a backdrop of the recently ended Vietnam War and the ongoing Cold War, a man wearing an expensive suit and a pseudonym walked into a granite finishing company in Elberton County, Georgia. He commissioned, from the bewildered owner, an elaborate and expensive monument on behalf of "an anonymous group of patriots." The 240,000-pound granite structure would function as a compass, calendar, and clock, complete with mechanisms for tracking the paths of the sun and stars, and was to be sandblasted with 10 guidelines for a 'rational' society, translated into eight languages. The monument was built to withstand the catastrophe and destruction its sponsors were sure was imminent. The guidelines etched onto its surface-which include the ominous instructions to "maintain humanity under 500,000,000" and "guide reproduction wisely" (Sullivan 2009) — implicitly imagine a world after calamity, suffused with hope for the growth of a better, brighter world filled with better, brighter people.

The enigmatic Georgia Guidestones are now a niche tourist destination and favorite topic of conspiracy theorists, but they are not the only American monument to preparedness and prophetic disaster to have arisen in the years since the start of the Cold War. From the network of fallout shelters that pepper the US to protocols designed to safeguard American infrastructure (Lakoff 2007), from the burgeoning number of 'doomsday preppers' (Mills 2019) to awareness of an acute climate crisis increasingly framed in apocalyptic terms (Webster 2013), narratives of decline are commonplace. Millennial beliefs are not the sole province of fringe movements; in fact, they have a long and varied history in the United States that ranges from the enigmatic to the perfectly quotidian. These extant American narratives are distinct from the kind of Buddhist temporality enacted by Tarthang Tulku and his students in important ways. However, the availability of both sacred and secular narratives of decline-from ecological collapse to the millennial rapture-means that the very idea that cataclysmic events like earthquakes might be part of a broader downward trajectory, and one with moral overtones, is, as per Robbins (2001) not 
such a fringe or unbelievable notion for Tarthang Tulku's prospective followers, but a familiar way of thinking through daily life. A significant part of the way TNMC confronts this temporal trajectory is through the safeguarding of Tibetan Buddhism's 'critical resources' in the form of sacred books and art-an approach markedly different from that of dispensational Christians, for example. This strategy is one with precedent in Tibetan Buddhist history, but it also sits comfortably alongside American notions of preparedness (Lakoff 2007), especially salient since the Cold War. Thus, once again Tarthang Tulku finds familiar threads in this American context to attach Tibetan Buddhist history and practice, shaping TNMC's particular approach to this age of decline.

Lakoff (2007) describes the rise of the concept of preparedness in the United States, which brings together a number of diverse collapse scenarios-from terrorist attacks to natural disasters- under the same banner as 'security threats'. Preparedness does not wonder whether calamity will happen, but when: "It enacts a vision of the dystopian future in order to develop a set of operational criteria for response" (ibid.: 253). Specifically, these criteria focus not on the protection of individuals, but the preservation of key infrastructures from which the system may be rebuilt. According to Anderson (2010: 791), the goal of preparedness, as directed at impending but vague catastrophic events, is to "build the capacity of 'resilience' into the very life that is to be secured." The Guidestones strikingly recall the flags TNMC has installed throughout California, with their Rosetta Stone-like potential to resurrect Tibetan Buddhism's wisdom in a new age. Both imagine a space after catastrophe, preparing antidotes and instructions to manage this period. In other words, they share a common approach to shoring up the kind of 'critical infrastructures' Lakoff describes, from which society may be resurrected in the wake of decline. In TNMC's case, this critical infrastructure is principally the Tibetan language, which holds the key to Tibet's Buddhist wisdom. The flags and the reference to the Kaliyuga they carry also exercise a similar ability to assimilate a wide range of types of threat under one narrative in the way that Lakoff designates.

TNMC's strategies to confront the prospect of a declining future may coincide with an American trend toward preparedness, and the availability of American narratives of decline in a broader sense may help to explain why Tarthang Tulku's Kaliyuga framing has resonated so far from Tibet's own landscape. However, the goals that guide TNMC's work differ in important ways from the approaches of 'preppers' or dispensationalists most readily associated with American eschatological beliefs and practices. The anonymous sponsor of the Georgia Guidestones admitted to an admiration for the unbending implacability of Stonehenge upon which he modeled his design (Bridges 1981). Unlike the Guidestones, the flags, wheels, and votives discussed here are not standoffish in their relationships to those of us living through decline. Rather, they are tangled up in their makers and their surroundings, both physically and narratively. They are not simply sitting atop the doomed landscape, but sinking into it, transforming it, colonizing as well as calming its threats. They sink into the very bodies of their makers, sending their urgency through the making. The Kaliyuga is not just a matter of distant scriptural warnings here, but an embodied and acute anticipation that saturates practitioners and their surroundings.

Even if the decline of the Kaliyuga is inevitable, the distant view of cyclic peaks to come means that looking beyond decline is possible and even imperative. The time between prophetic peaks in dispensational belief and practice is sometimes referred to as a 'lacuna' (Guyer 2008) or a 'parenthetical' period (Robbins 2001), characterized chiefly by vigilant attention to the horizon while awaiting the telltale signs of the cataclysm to come. The Buddhist valley for Tarthang Tulku's students, by contrast, is no period of watchful waiting, but rather one of intense activity characterized by stockpiling, collecting, protecting, and preparing sacred resources. This is 
done, I suggest, in a spirit similar to that of Lakoff's preparedness: not in order to avert the catastrophe, but in order to manage its fallout.

In terms of TNMC's projects, the system to be rebuilt is no less than Tibetan Buddhism itself. The projects undertaken by TNMC are often deployed to treat an immediate need-to restock Tibetan monastic libraries, to quell tsunamis, to heal troubled earth. But underlying these immediate functions is a project of proliferating and caching materials that could foster the regeneration of the sangha, the Buddhist community. This stockpiling, then, is conducted in a manner very different from, say, the way 'preppers' might stock a personal bunker. The very production of this material is a meritorious act that fortifies us all against the Kaliyuga in an attempt to ease humanity's decaying karma. Further, these stores of sacred material also look far beyond the use of their immediate creators to an imagined future discoverer who might reap the rewards of TNMC's careful work for the benefit of the sangha and all humanity.

This approach is not unique to TNMC, nor is it a new strategy. The centrality of the Tibetan language and script to Tibetan Buddhism is critical, Sakyamuni himself having prophesied to his followers (as recounted in the Prajñāpāramitāsūtra, a set of texts in the Mahayana Buddhist tradition that translates as "The Perfection of Wisdom") that after his death he would persist in the form of the written word during the "degenerate era" (Diemberger 2012: 12), and that their main reprieve during the Kaliyuga would lie in the sacred texts that held his sutras: their proliferation, spread, and careful custody (Empson 2006; Nattier 1991). ${ }^{8}$ The language, therefore, that is safeguarded so carefully in TNMC's sacred flags amounts to the critical infrastructure of Tibetan Buddhist wisdom. ${ }^{9}$ The practice of investing the persistence of Buddhist wisdom in text is especially pronounced in Tibetan Buddhism and is specifically manifest in practices of caching in Tarthang Tulku's Nyingma school. Nyingma Buddhism has a robust and long-standing practice, called the gter ma tradition, of cyclic concealment and revelation of 'secrets', usually secret texts cached in mountains, rivers, or valleys for rediscovery at opportune moments. Often credited with the safeguarding of the Nyingma lineage through periods of upheaval or threat (Diemberger 2012; Germano 2002; Smith 1970; Tulku Thondup Rinpoche 1986), the gter ma tradition has been experiencing a renaissance among the Nyingmapa in Tibet since the 1970s (Germano 1998). This renaissance is unsurprising given the threats to the Tibetan Buddhist textual lineage in recent decades that, through the cyclic reckoning of periods of threat, concealment, and revelation, call upon the Nyingmapa strategies of concealment in order to weather these storms, as they have done in the past.

For Nyingma practitioners, it is Padmasambhava-deeply beloved of the Nyingmapa and recognized by them as a second Buddha-who, in his transcendent wisdom, determines where and when a text ought to be hidden and then revealed. The figures who later discover the hidden gter ma earn the title Tertön (Tib. gter ston), or 'treasure revealer', in doing so (Tulku Thondup Rinpoche 1986). Based on their relationship with Padmasambhava, valleys take on a particular significance for the Nyingmapa in the form of beyul (Tib. sbas yul), hidden valleys considered places of sublime peace and earthly paradise. Many of these places lie as yet undiscovered, their location kept secret by Padmasambhava who will reveal them as places of refuge for practitioners when the outside world is swallowed by strife (Orofino 1991; Reinhard 1978). The idea of the beyul providing refuge for practitioners specifically from the hardships of the Kaliyuga is linked to prophetic texts attributed to Padmasambhava. ${ }^{10}$

Tarthang Tulku does not claim the title of Tertön for himself, nor has Padmasambhava revealed a beyul to him. He has, though, perhaps endeavored to create a space that is at least inspired by such a valley in Sonoma through the busy stockpiling, interring, and safeguarding of Tibetan Buddhist textual material across California. His practices and the significance of Sonoma's valley in TNMC's preservative strategies are clear heirs to the Nyingma traditions of gter ma and beyul. In this way, the parallel established between Padmasambhava and Tarthang Tulku through 
Odiyan-casting Tarthang Tulku as the bringer of Buddhism to California and the subduer of its landscape-is borne out in his concentrated efforts to protect the dharma in this degenerate age by stockpiling sacred objects he has created and scattered throughout the topography.

This safeguarding is expressed across TNMC's many projects. Take, for example, the production of prayer wheels undertaken in this California community. Ubiquitous features of Tibetan landscapes, prayer wheels may range from small handheld devices to structures several feet tall. These objects are considered exceptionally powerful merit fields endowed with the ability to effect 'readings' of thousands of mantras at once as they spin. Prayer wheels have the powerful capacity to purify even the most negative karmas or those of oblivious passersby "whose minds are so obscured and filled with disturbing thoughts, like an ocean covering a whole city, and who are extremely lazy and ignorant" (Lama Thubten Zopa Rinpoche 2000: ix). The despairing assessment of sentient beings in this passage, for which the prayer wheel is a remedy, resonate here in particular as prayer wheels destined to be installed in America have the monumental task of purifying the karma of a population largely unaware of their very existence.

TNMC's prayer wheel studio is managed by Ray, the aforementioned Tibetan teacher. Working with the prayer wheels is a relatively restricted appointment, and the studio is private in spite of the teeming presence of the wheels at every property TNMC owns. I was lucky enough to be given a tour of the studio when the community van I was helping to load with printing materials fortuitously stalled right outside. Ray showed me reverently through a series of dimly lit rooms with low ceilings. Cluttered with spools of wire, enormous reams of paper, and myriad bits of assorted machinery, they were pervaded by the soft hum of the motors that keep TNMC prayer wheels spinning. Ray gestured me over to a pile of large sheets of thick white paper, handing me a magnifying glass and inviting me to look closely to see the minute red Tibetan font that covered the pages. Satisfied that I was suitably impressed, Ray then handed me a small canister the size of a roll of film and explained that inside was a scroll of microfilm upon which was printed the entire Kanjur (Tib. bka' 'gyur), often colloquially called the Tibetan Buddhist 'canon'. This significant adaptation coordinated by Tarthang Tulku speaks to the singular focus on the preservation of text. It is traditional for Tibetan prayer wheels to contain copies of the mani mantra, ${ }^{11}$ but the wheels produced here contain entire texts or even multiple copies of complete texts.

It is no coincidence, I think, that one of the community's dearest lovers of the Tibetan language is responsible for this project with its inherent gravity. The responsibility entrusted to him is a fact that Ray reflects upon often. He and I spoke about his work with the prayer wheels, and he joked at the unlikely paths that had led him, with all his considerable education and credentials, to spending his days gluing pieces of paper together in a basement. But he explained that Tarthang Tulku has assuaged his occasional doubts about the value of this work, helping him to understand the "futility and the shallowness and the hollowness of professional activity" and impressing upon him that
those who are on the side of the Dharma are very few and far between ... and that the tradi- tion has been placed in great peril. And so he really impressed upon us that this historical juncture with the endangerment of the tradition in Tibet and the introduction of this new- born infant tradition in the West was a very dicey time, and that anything that we could do to bring more energy and more concentration to it would be of particular value and importance. (Interview, 25 August 2016)

This association between the prayer wheels and the desperate condition of the dharma is reflected in wider community missives beyond Ray's singular experience. A website dedicated specifically to the TNMC prayer wheel project, entitled "Prayer Wheels for World Peace," describes the function of prayer wheels thus: 
In recent years, the world has seen how quickly knowledge-even when valued and protected by an entire culture-can be brought to the brink of extinction. In response, we have made great efforts to preserve the cultural heritage of Tibet, including the intricate science of dharma wheels, which are in themselves ways of preserving and disseminating the benefits of enlightened knowledge ... [W] have come to share the view that dharma wheels have a calming and healing influence on the environment and human beings, qualities greatly needed in our world today. ${ }^{12}$

This passage deftly invokes an understanding of the pervasive suffering and decline afflicting our present world, although this sentiment is ambiguous in terms of its secularity or religiosity. It also taps into another facet of the available American themes of decline: diagnoses of cultural endangerment and loss that are especially pervasive in the present moment (Berliner 2014). This is not to say that these discourses are entirely new, but that anxieties over 'losing culture' are increasingly a part of mainstream zeitgeist. Further, such fears are often expressed in terms that are markedly apocalyptic in their expression of a "crisis in cultural transmission" (ibid.: 18), instigated by globalization, neoliberalism, climate change, and a host of other broadly conceived threats (ibid.: 29). Thus, narratives of decay call attention not only to the environmental or topographical, but also the more symbolic registers of life.

The rhetoric of embattled, precarious culture is starkly reminiscent of the position Tibet has taken up in international spheres of cultural lobbying, where Tibet stands as a 'traditional' holdout against China's modern machine. Ray clearly reflected this facet of the American imagination of Tibet when he explained to me how he first came to study with Tarthang Tulku:

I was born here in Berkeley in 1954 ... [and lived here when] I was in high school, and so at that time the Vietnam War was in full flame and I was approaching my eighteenth birthday which would make me eligible to be drafted and sent over there, and so there was a lot of angst about that ... and the images of the war were, you know, a steady stream on the evening news in a very different way that you don't see now ... [B] ack then you actually got battle footage, I mean, it was very grotesque and uncensored in a way that's not true today. So, it was very vivid and it was pretty much a steady dose of it every night. And so there I was, you know, as a teenager confronted with that and confronted with a sense of the despoilment of the Western wilderness here in the United States, particularly because we had a family cabin at Lake Tahoe in the Sierra and we were seeing high-rise casinos being built against this pristine landscape, you know. And so those two things, as I say the wartime violence and the despoilment of the environment created in me a very distinct sense that the culture that I was familiar with, Western culture in general, whatever, was somehow fundamentally lacking or missing the boat. That the philosophy and religion and cultural values that would lead to these kind of outputs ... something was wrong, something was deeply flawed. So that led to an exploration, starting into Asian philosophies. (Interview, 25 August 2016)

Ray conveys a vivid image of coming into adulthood under a pall of overhanging violence and destruction - a condition of sick spiraling for which, it seemed to him, there might be a balm in the "Asian philosophies" he was drawn to in college. This narrative was not so uncommon at all among the initial cohort of Tarthang Tulku's students: Californian youth of the 1960s and 1970s, deeply familiar with, and yet disenfranchised with, their parents' Christianity and coming to terms with a world that seemed to them fundamentally sick. Tarthang Tulku's framing of Tibet's endangered heritage, its precious and threatened textual lineage, resonated deeply both with the sense of threat and the kind of seeking for a new remedy these would-be followers expressed.

Thus, the stockpiling and caching of flags, prayer wheels, tsha-tshas, and sacred books are a multivalenced effort that addresses at once Tibetan Buddhism's and the world's contemporary precarity and sense of future threat. What I have intended to show is that the specific Buddhist 
properties of the Kaliyuga, or even its religiosity more generally, is not always its most salient feature. By contrast, it is perhaps the fact that the way TNMC approaches the Kaliyuga fits neatly among a repertoire of apocalyptic and preparedness themes already in motion in the American context that is their sustaining attribute here. The approach to mitigating the accelerating decline - through intense stockpiling and safeguarding-certainly speaks to a relationship between TNMC's relative eschatology and Nyingma heritage that connects fluidly with extant preparedness strategies, distinguishing both from the dispensational watchfulness that often shapes our understanding of American eschatology.

\section{A Problem of Urgency: Decline, Landscape, and Body}

An undercurrent of preparedness sentiment, buoyed by the effects of the Cold War on the American understanding of the future, undoubtedly helped to shape the way TNMC's particular relative eschatology appeals to its members. However, the redemptive peak in Kaliyuga reckoning is much more distant than that imagined in, for example, the Georgia Guidestones. What results is a problem of urgency, the challenge of maintaining a sense of immediate need for action in the face of a timescale that is staggering in its length.

Part of the strategy for maintaining this urgency lies in the skillful colonizing of pre-existing threats-like the earthquakes so salient to Californians-drawing them into Tibetan Buddhist narratives. The prophetic valley we occupy is, for Tarthang Tulku and his students, one of intense and concentrated activity. The temporal valley invests California's topographical valleys with new layers of meaning, as these spaces are rendered potent caches for the Nyingma secrets that will await new revelation on spiritual peaks to come. This capitalizing on a readily available awareness of imminent danger allows TNMC to propel its members to partake in focused, urgent action as they set out to create and cache their own sorts of guidestones. However, the impression of urgent need upon TNMC members extends further than references to natural disasters: in fact, the way projects are configured ensures that volunteers are drawn bodily into the narratives held by the objects they create.

The principal way volunteer-practitioners in Tarthang Tulku's fold come to access cyclic and prophetic temporality is through the process of creating sacred objects. These objects are both testaments to and remedies for the symptoms of the Kaliyuga. Through projects of sacred-making, prophetic temporality bursts the boundaries of the distant future to soak the bodies and temporal sensibilities of their makers. The physical dimension of creating sacred objects is, in this instance, a significant way in which the sense of urgency is impressed bodily into practitioners, brought into the everyday and fixed to the landscape around them. The sense of inevitable decline has powerful affective and bodily consequences as the message of the Kaliyuga is channeled through physical practice in a way that outstrips even the most emphatic scriptural warnings.

One of the hallmarks of the volunteers who populate Tarthang Tulku's community is the staggering magnitude of projects they undertake and the speed at which they work. The accomplishments of this group of heterogeneous volunteers are truly impressive; however, their commitment to work is not simply zeal but rather a feature of the way Tarthang Tulku directs the practice of his followers. Project timelines at TNMC keep volunteers moving at an extraordinary pace, often while they grapple with machinery, techniques, and materials with which they have little training or experience. This approach, coupled with the emphatic and prophetic qualities of the sacred materials themselves, creates an atmosphere of urgency that is acutely felt and expressed by my interlocutors. Volunteers at the entry level work six-day weeks and often ten-hour days-with generally even longer hours for those who have been with TNMC for many years. 
One such volunteer and long-time community member, Grace, discussed this sense of urgency with regard to tsha-tsha making. These votives are cast, sanded, painted, gold-leafed, and distributed by the thousands by TNMC members and are frequently a gateway to sacredmaking for new volunteers. Grace described one particular tsha-tsha project where Tarthang Tulku had set a deadline for a quota of the votives that she and her workmates knew categorically, empirically, and emphatically to be impossible. They had timed their tsha-tshas per hour production rate on their best days, and they still were nowhere near the pace needed to meet their new target. And yet, the team shut themselves up in a shed, chanted mantras together, and somehow managed to fill their impossible quota. "At one point," Grace told me, "I was like 'this is not possible, and then we somehow did it, you know what I mean? It was one of those. I was literally convinced it was impossible. That gives you a little taste because that's a thing you hear a lot around Rinpoche's [Tarthang Tulku's] projects."

The intensity Grace referred to, rather than being simply a result of unpredictable deadlines, is a routine pressure that Tarthang Tulku intentionally structures into projects of sacred-making. Last-minute drastic changes in instructions are such common occurrences across the TNMC organizations that volunteers repeatedly pointed out the pattern to me as Grace did (usually with good humor and wry resignation). Grace and the team of tsha-tsha makers responded to this challenge in the ideal way-through immersive focus, whose power Grace wondered at long after the completion of the project.

Through this desperation brought on by deadlines and the resultant heightened focus, volunteers' very bodies become saturated with the urgency that surrounds sacred art and its making. Tsha-tshas in this community emerge as one of a complement of important future-looking and future-making tools. Their use is predicated on an understanding of a precarious present (and future) and of a landscape that must be stabilized and placated. Such an understanding is conveyed to volunteers not simply through the ways in which tsha-tshas and other art objects are deployed, but also through the very process of making them, a process that draws makers into the temporality of prophecy, decline, and urgency. Sacred art projects, then, are a critical tool, both for counteracting the envisaged precarious future and for communicating the pressing nature of that very future on volunteers.

The investment of these art objects into the landscape is also significant; each object is carefully designed and placed in order to influence its surroundings. But they do more than effect a Tibetan Buddhist remedy for disasters and negative karma. They in fact 'Buddhify' the landscape. Objects of the sort TNMC creates-flags, stupas, and tsha-tshas-have long been tools used by those who would propagate Tibetan Buddhism in new soil (Huber 2008). For example, stupas, often the markers of pilgrimage routes, are more than passive indicators; instead, they sanctify and 'Buddhify' the terrain itself, acting as ubiquitous markers of Buddhist presence (Bentor 1996; Farkas and Farkas 2009; Germano 1998; Huber 2008; Tucci [1932] 1988). Proliferating such objects in the California landscape serves to impress a Tibetan Buddhist narrative on this new territory, colonizing its features and threats (such as earthquakes) and rendering them a part of Tibetan Buddhist cyclic time.

Doreen Massey (2013) famously described space as a "pincushion of a million stories." Here, sacred art objects are the pins that affix Tibetan narratives and histories to the landscapes inhabited by American practitioners; they are a key part of bringing this distant landscape into the progression of Tibetan history. Through their bodily investment in creating these objects, volunteers are entangled in this narrative as well, being coaxed into a new temporal framework. Through training and control exerted over their bodies in the process of making sacred objects, volunteers are taught to recognize the distinct sense of urgency coupled with imaginaries of disaster. This urgency is impressed physically on volunteers through the seemingly unattainable 
deadlines they report as standard. This approach to the creation of sacred art offers an avenue through which the distant realities of the Kaliyuga are demonstrated as latent in the present moment, allowing an engagement with futurity that is acutely concerned with both the very near and the very distant future at once.

\section{Conclusion}

I have attempted to show how Buddhism's relative eschatology becomes a kind of everyday millennialism for the Tibetan Nyingma Meditation Center members. Not only do the Nyingma prophecies of decline I have discussed here fail to fuel a withdrawal from the world, but they are explicitly mapped onto everyday practices. The specters of the Kaliyuga are so consistently present-in earthquakes, for example - that Tarthang Tulku appears to intentionally structure a sense of urgency into the practices of his students lest decline become too quotidian a reality.

Further, specters of decline and the urgent need to prepare for a world in decay are salient themes in spheres outside the strictly religious. They resonate with contemporary American rhetorics of preparedness, which hinge on a pervasive belief that "things are just bad and getting worse," as one interlocutor put it. Narratives of impending loss and degeneration also find resonance in popular nostalgic narratives of endangered cultures atrophying under the strain of inexorable modernity that are very familiar to Tarthang Tulku's community members. TNMC's volunteers move ably across these registers as they advocate for their work. Relative eschatology, then, begins to appear not as the niche province of fringe religious movements, but rather as a kind of affective thread with a growing presence in the sacred landscape as well as in secular narratives of preparedness, cultural endangerment, and ecological crisis.

This account is also intended to add nuance to the association between Tibetan Buddhism in America and nostalgic traditionalism that has become something of a trope. Potent nostalgia and narratives of cultural endangerment are undoubtedly at play for Tarthang Tulku and his students. However, I suggest that a forward-looking stance is not precluded by the nostalgia that is often present in American Tibetan Buddhism. In fact, they complement one another well: reaching for Buddhist wisdom to counteract the ills of modernity echoes the Western propensity since the early twentieth century to view Tibet as a source for spirituality to counteract the corresponding spiritual deficit in the West (Neuhaus 2012). Thus, TNMC members use traditional Tibetan Buddhist tools to shore up the American landscape. Even-and perhaps especially-in the production of traditional sacred forms, vivid futures are imagined and addressed. Such prophetic narratives of destruction, often assumed to be the province of millennial Christians, are underattended in American Buddhist communities like this one.

For TNMC, decline and disaster are potential invested in the everyday. Further, they are specifically invested in the Tibetan Buddhist sacred text and art that this community labors to produce. Sacred art and texts are portents of the Kaliyuga-containing, describing, and depicting this dark age-but they also offer the only avenue for mitigating the effects of this inevitable slide. Their physical making, then, saturates TNMC's volunteers with the narratives that are invested in sacred art and text. So too is the surrounding terrain saturated, both physically, as it teems with buried tsha-tshas, spinning wheels, and flying flags, and narratively, as California's valleys become sanctified and filled with Tibetan Buddhist secrets. This process of investing American soil with Tibetan secrets imagines futures both near and far-the looming earthquakes, storms, and other disasters that threaten to strike at any moment, and an almost imperceptibly distant peak where Maitreya’s influence heals and makes whole these fissures. 


\section{ACKNOWLEDGMENTS}

I am indebted to the volunteers at the Tibetan Nyingma Meditation Center for their unfailing patience and warmth. The fieldwork upon which this article is based would not have been possible without contributions from the Social Sciences and Humanities Research Council, the Cambridge Trust, Jesus College Cambridge Graduate Research Fund, and the Cambridge University Fieldwork Fund. This work was also supported by the Smuts Memorial Fund, managed by the University of Cambridge in memory of Jan Christiaan Smuts. I wish to thank the reviewers for their thoughtful and immensely helpful feedback on earlier drafts of this article.

AMY BINNING received a PhD in Social Anthropology from the University of Cambridge in 2019, before which she received a BA in Anthropology from McGill University and an MRes in Social Anthropology, also from the University of Cambridge. She is currently a Postdoctoral Fellow in the Anthropology Department at McGill University. Her research interests include anthropology of religion; Tibetan Buddhism in North America; the materiality and media of religion; Canada's pro-Tibet lobby landscape; and governance, activism, and citizenship in the Tibetan diaspora. E-mail: amy.binning@mcgill.ca

\section{NOTES}

1. A Pulitzer Prize-winning New Yorker article on the subject recently petrified a wide readership (Schulz 2015).

2. TNMC is populated almost entirely by residential worker-volunteers, who conduct many such projects year round.

3. Interlocutors names have been changed.

4. Crucially, this does not mean that the inherent truth of Buddhist doctrine is impermanent, only its institutions and practitioners.

5. Composed by the Buddhist monk and philosopher Vasubandhu around the fifth century CE, the Abhidharmakośa has been translated and studied across multiple Buddhist traditions and languages including the Tibetan schools.

6. While there are clear continuities between the Hindu and Buddhist ideas of decline, Nattier (1991) points out a key difference: the Hindu writings on temporal progression include no upward-moving periods, only successive declines punctuated with periods of 'non-manifestation'.

7. There have been a few studies of Buddhist movements of this sort that describe the rare appearance of fringe messiahs in Buddhist countries. See, for example, Malalgoda (1970) and Ladwig (2014).

8. TNMC's central project is the huge-scale production of sacred texts for distribution to the Tibetan monastic population in India. However, the full gamut of sacred objects they produce-including flags, tsha-tshas, prayer wheels, and stupas-are also created in fulfillment of the Buddha's instructions. In Tibetan Buddhist contexts, the line between sacred texts and other sacred objects is often markedly flexible, since the Tibetan script itself is understood as sacred and sanctifies other objects through its incorporation in their making.

9. It may seem unusual, then, that Tarthang Tulku's students are not strongly encouraged to study the classical Tibetan language. However, Tibetan texts have a long history of impacting even those unable to read them through the inherent power of the script itself (Diemberger 2012). Further, the caching of such material looks beyond the immediate use of Tarthang Tulku's students to a hopeful resurgence of the Buddhist sangha more broadly. 
10. One such prophetic text is the sbas yul spyi'i them byang. Revealed in the fourteenth century, this gter ma outlines several signs-such the destruction of Tibet's temples and people turning to the consumption of their own father's flesh-that will indicate it is time for the worthy to seek entry to these hidden lands (Orofino 1991: 240).

11. The om mani padme hum is a ubiquitous and powerful mantra sometimes understood to distill the essence of Buddhism's teachings, and whose six syllables in Tibetan reckoning correspond to various significant groupings of six (such as realms, deities, colors, and the six perfections) (Lopez 1998).

12. http://www.nyingma.org/PrayerWheels/index.html (accessed on 26 September 2019).

\section{REFERENCES}

Anand, Dibyesh. 2007. Geopolitical Exotica: Tibet in Western Imagination. Minneapolis: University of Minnesota Press.

Anderson, Ben. 2010. "Preemption, Precaution, Preparedness: Anticipatory Action and Future Geographies.” Progress in Human Geography 34 (6): 777-798. https://doi.org/10.1177/0309132510362600.

Apple, James B. 2010. "Eschatology and World Order in Buddhist Formations." Religious Studies and Theology 29 (1): 109-122.

Barnett, Robert. 2001. “Violated Specialness': Western Political Representations of Tibet.” In Imagining Tibet: Perceptions, Projections, and Fantasies, ed. Thierry Dodin and Heinz Räther, 269-316. Boston: Wisdom Publications.

Bentor, Yael. 1996. Consecration of Images and Stūpas in Indo-Tibetan Tantric Buddhism. Leiden: Brill.

Berliner, David. 2014. “Are Anthropologists Nostalgist?” In Anthropology and Nostalgia, ed. Olivia Angé and David Berliner, 17-34. New York: Berghahn Books.

Bogin, Benjamin. 2014. "Locating the Copper-Colored Mountain: Buddhist Cosmology, Himalayan Geography, and Maps of Imagined Worlds." Himalaya, the Journal of the Association for Nepal and Himalayan Studies 34 (2). https:/ https://digitalcommons.macalester /digitalcommons.macalester. edu/himala.edu/himalaya/vol34/iss2/5.

Borjigin, Uranchimeg. 2006. “Circulating Prophetic Texts.” In Empson 2006, 21-60.

Bridges, Bill, ed. 1981. The Georgia Guidestones. Elberton, GA: Elberton Granite Finishing.

Collins, Steven. 1998. Nirvana and Other Buddhist Felicities: Utopias of the Pali Imaginaire. Cambridge: Cambridge University Press.

Dalton, Jacob P. 2011. The Taming of the Demons: Violence and Liberation in Tibetan Buddhism. New Haven, CT: Yale University Press.

Diemberger, Hildegard. 2012. "Holy Books as Ritual Objects and Vessels of Teaching in the Era of the 'Further Spread of the Doctrine' (Bstan pa yang dar)." In Revisiting Rituals in a Changing Tibetan World, ed. Katia Buffetrille, 9-41. Leiden: Brill.

Empson, Rebecca, ed. 2006. Time, Causality and Prophecy in the Mongolian Cultural Region: Visions of the Future. Folkestone: Global Oriental.

Farkas, Richard, and Julie Farkas. 2009. "Religion in the Life and Landscape of Tibet." Focus on Geography 52 (2): 30-37. https://doi.org/10.1111/j.1949-8535.2009.tb00245.x.

Germano, David. 1998. "Re-membering the Dismembered Body of Tibet: Contemporary Tibetan Visionary Movements in the People's Republic of China." In Buddhism in Contemporary Tibet: Religious Revival and Cultural Identity, ed. Melvyn C. Goldstein and Matthew T. Kapstein, 53-94. Delhi: Motilal Banarsidass.

Germano, David. 2002. "History and Nature of the Collected Tantras of the Ancients." Tibetan and Himalayan Library, 25 March. http://www.thlib.org/encyclopedias/literary/wiki/history\%20of\%20 ngb.html.

Guyer, Jane I. 2008. "Prophecy and the Near Future: Thoughts on Macroeconomic, Evangelical, and Punctuated Time." American Ethnologist 34 (3): 409-421. https://doi.org/10.1525/ae.2007.34.3.409.

Hess, Julia Meredith. 2006. "Statelessness and the State: Tibetans, Citizenship, and Nationalist Activism in a Transnational World." International Migration 44 (1): 79-103. 
Huber, Toni. 1999. The Cult of Pure Crystal Mountain: Popular Pilgrimage and Visionary Landscape in Southeast Tibet. New York: Oxford University Press.

Huber, Toni. 2008. The Holy Land Reborn: Pilgrimage and the Tibetan Reinvention of Buddhist India. Chicago: University of Chicago Press.

Ladwig, Patrice. 2014. "Millennialism, Charisma and Utopia: Revolutionary Potentialities in Pre-modern Lao and Thai Theravāda Buddhism." Politics, Religion \& Ideology 15 (2): 308-329.

Lakoff, Andrew. 2007. "Preparing for the Next Emergency." Public Culture 19: 247-271. https://doi. org/10.1215/08992363-2006-035.

Lama Thubten Zopa Rinpoche. 2000. "Foreword.” In The Wheel of Great Compassion: The Practice of the Prayer Wheel in Tibetan Buddhism, ed. Lorne Ladner, vii-xiii. Boston, MA: Wisdom Publications.

Lopez, Donald S., Jr. 1998. Prisoners of Shangri-La: Tibetan Buddhism and the West. Chicago: University of Chicago Press.

Macdonald, Alexander W. 1996. Mandala and Landscape. New Delhi: DK Printworld.

Malalgoda, Kitsiri. 1970. "Millennialism in Relation to Buddhism." Comparative Studies in Society and History 12 (4): 424-441.

Massey, Doreen. 2013. "Doreen Massey on Space." Interview with Nigel Warburton. Social Science Bites in association with SAGE. Podcast audio, 1 February. https://www.socialsciencespace.com/2013/02/ podcastdoreen-massey-on-space/.

McMahan, David L. 2008. The Making of Buddhist Modernism. New York: Oxford University Press.

McMahan, David. 2017. "Buddhism, Meditation, and Global Secularisms." Journal of Global Buddhism 18: 112-128. http://www.globalbuddhism.org/jgb/index.php/jgb/article/view/197.

Mills, Michael F. 2019. "Preparing for the Unknown ... Unknowns: 'Doomsday' Prepping and Disaster Risk Anxiety in the United States." Journal of Risk Research 22 (10): 1267-1279.

Nattier, Jan. 1991. Once upon a Future Time: Studies in a Buddhist Prophecy of Decline. Berkeley, CA: Asian Humanities Press.

Nattier, Jan. 2008. "Buddhist Eschatology." In The Oxford Handbook of Eschatology, ed. Jerry L. Walls, 151-169. New York: Oxford University Press.

Neuhaus, Tom. 2012. Tibet in the Western Imagination. New York: Palgrave Macmillan.

Orofino, Giacomella. 1991. "The Tibetan Myth of the Hidden Valley in the Visionary Geography of Nepal." East and West 41 (1-4): 239-271.

Reinhard, Johan. 1978. "Khembalung: The Hidden Valley." Kailash: A Journal of Himalayan Studies 6 (1): 5-35.

Robbins, Joel. 2001. "Secrecy and the Sense of an Ending: Narrative, Time, and Everyday Millenarianism in Papua New Guinea and in Christian Fundamentalism." Comparative Studies in Society and History 43 (3): 525-551.

Schulz, Kathryn. 2015. “The Really Big One.” New Yorker, 13 July. https://www.newyorker.com/ magazine/2015/07/20/the-really-big-one.

Smith, E. Gene. 1970. “Introduction." In Kongtrul's Encyclopaedia of Indo-Tibetan Culture, ed. Lokesh Chandra. New Delhi: International Academy of Indian Culture.

Smyer Yü, Dan. 2012. The Spread of Tibetan Buddhism in China: Charisma, Money, Enlightenment. London: Routledge.

Sullivan, Randall. 2009. "American Stonehenge: Monumental Instructions for the Post-Apocalypse." Wired, 20 April. https://www.wired.com/2009/04/ff-guidestones/.

Tucci, Giuseppe. (1932) 1988. Stupa: Art, Architectonics and Symbolism, ed. Lokesh Chandra; trans. Uma Marina Vesci. New Delhi: Aditya Prakashan.

Tulku Thondup Rinpoche. 1986. The Hidden Teachings of Tibet: An Explanation of the Terma Tradition of the Nyingma School of Buddhism, e d. Harold Talbott. London: Wisdom Publications.

Webster, Joseph. 2013. “The Eschatology of Global Warming in a Scottish Fishing Village." Cambridge Journal of Anthropology 31 (1): 68-84. https://doi.org/10.3167/ca.2013.310106. 